\title{
An Experimental Investigation on Four Stroke CI Engine by Comparing Performance Parameters and Emission Characteristics with Two Bio-Diesel Blends and Diesel as Fuel: Hazelnut and Safflower
}

\author{
T. Krishnaiah ${ }^{1}$, Dr. V. Pandurangadu ${ }^{2}$ \\ ${ }^{1}$ M.Tech, (Ph.D), Department of Mechanical, Gates Institute of Technology, Gooty, Anantapur, Andhra Pradesh, India \\ ${ }^{2}$ Ph.D, Professor, Department of Mechanical, Rector, JNTUA, Anantapuramu, Anantapur, Andhra Pradesh, India
}

\begin{abstract}
An experimental evaluation was made to investigate and compare the results of two non edible bio-diesels namely Hazelnut and safflower. Bio-diesel blends will be prepared with these fuels by mixing with normal diesel fuel with suitable proportions of 5\%, $10 \%, 15 \%, 20 \%$ and $25 \%$ of hazelnut ang safflower bio-diesels separately by volume and used as a fuel in a vertical, four stroke, water cooled, mono cylinder, Compression Ignition engine by using the above fuel blends as fuel, numbers of experiments will be computed with the engine working at different loads. A comparative investigation was executed on the performance parameters such as Brake Thermal efficiency (BTHE), Brake Specific fuel Consumption (BSFC) and Exhaust Gas Temperatures (EGT) and on exhaust emission like oxides of nitrogen (NOx), oxides of carbon (CO), total and partially unburned hydro carbons and smoke density. The bio diesels which are considered as most promising alternative fuels are prepared from vegetable oils. Among all the industries in the world bio fuel production is one of the rapidly growing industries. Here in this study hazelnut bio-diesel blands are giving better performance parameters and lower exhaust emissions compared with remaining bio-diesel blends made with safflower.
\end{abstract}

Keywords: hazelnut, safflower, bio-diesel blends, diesel, performance parameters and emission characteristics

\section{Introduction}

Apart from renewability, bio-fuels are more advantageous than normal diesel in some aspects like they are having very less sulphur content and aromatic contents, higher lubricity, higher flash point, non-toxicity and higher bio-degradability. On the other side the disadvantages of bio-fuels includes very high pour point, very high viscosity, the lower cetane number, lower volatility and lower calorific value. One of the great disadvantages of bio-fuel is its highly increased viscosity, which is approximately 10-20 times greater than normal diesel fuel. More over short term tests by using biofuels are giving promising results but when engine has been operated for longer periods then problems are appearing, which includes more carbon deposits, injector coking with trumpet formation, piston oil ring sticking, as well as the thickness of engine lubricating oil also increases. The following methods are adopted to avoid the problems associated with their high viscosity. Micro emulsification with methanol or ethanol blending in small blend ratios with diesel fuel, cracking, preheating and conversion in to bio-fuel mainly through the transisterification process. [22-25].

The advantages of bio-diesels as diesel fuel, apart from renewability, are the minimal sulfur and aromatic content, the higher flash point, the higher lubricity, the higher cetane number, and the higher biodegradability and non-toxicity. On the other hand, their disadvantages include the higher viscosity (though much lower than the vegetable oils one), the higher pour point, the lower calorific value and the lower volatility. Furthermore, their oxidation stability is lower, they are hygroscopic, and as solvents they may cause corrosion of components, attacking some plastic materials used for seals, hoses, paints and coatings. They show increased dilution and polymerization of engine sump oil, thus requiring more frequent oil changes.

Because of all the above reasons, maximum up to $25 \%$ of bio-fuels and vegetables are generally accepted as blends with diesel fuel and can be used in existing diesel engines without modifications. Experimental studies on the CI engines with the use of bio-fuels blending with neat diesel have been reported.

The present experimental work studies and compares the above bio-fuels of various origins, in blending with ordinary diesel fuel, by fuelling a single cylinder, direct injection, naturally aspirated CI engines. A companion paper extended the present investigation for hazelnut oil and its methyl esters for different blend ratios, followed by another paper dealing with their heat release and stastical analysis using insulated combustion chamber of the same engine.

As mentioned above, the results of performance and emissions have been evaluated by this research work by using blends of neat diesel fuel with two bio-fuels (hazelnut oil and safflower oil) [28], in the single-cylinder, watercooled, direct injection, 'kirlosker' diesel engine concerning the present work. The interpretation of the experimental measurements was based on the differences of properties between the fuels tested.

Most of the experimental works reported on the use of biofuels in the compression ignition engines are referred to mainly single-cylinder naturally aspirated engines have been used only one or two bio-fuel oils. But the present research work steps forward in reporting on the use of two bio-fuel 


\section{International Journal of Science and Research (IJSR) \\ ISSN (Online): 2319-7064}

Index Copernicus Value (2013): 6.14 | Impact Factor (2015): 6.391

oils on a single-cylinder, four stroke and water-cooled diesel engine.

Widely differing chemical and physical properties of biofuels against those of diesel fuels, are combining with the theoretical aspects of diesel engine combustion, and are used to aid the correct interpretation of the observed engine emissions and performance wise behavior.

\section{Description of the Engine Test Facility}

Facilities to monitor and control engine variables were installed on a test-bed, Kirloskar single cylinder, four stroke, vertical, water cooled, compression ignition engine (Fig. 1) was used and mounted on the ground. The test engine was directly coupled to an eddy current dynamometer with suitable switching and control facility for loading the engine. Engine specifications were as follows: bore \& stroke, $87.5 \mathrm{~mm}$ x 110 $\mathrm{mm}$; compression ratio, 17.5: 1; speed, $1500 \mathrm{rpm}$; fuel timing, $27^{\circ}$ by spill (btdc); clearance volume, $37.8 \mathrm{cc}$; and rated power, $5 \mathrm{hp}$.

For fuel consumption measurement a tank and flow metering system is used for various blend samples as follows. A piezometer of known volume was used with the measurement of time for the complete evacuation of the sample fuel which is feeding to the engine. In order to have a quick drain of a fuel sample, including the return fuel from injector and pump and refilling of fuel metering system with new fuel sample a system is provided with valves and pipes.

A system which is used for the measurement of exhaust gases consists of group of analyzers for measuring carbon monoxide $(\mathrm{CO})$, oxides of nitrogen $\left(\mathrm{NO}_{\mathrm{x}}\right)$, hydrocarbons $(\mathrm{HC})$, smoke density (SD), particulate and soot. The concentration of CO (in ppm) present in the exhaust gases was measured by using 'Signal' Series-7200 non-dispersive infrared analyzer (NDIR) equipped with a 'Signal' Series-2505M Cooler. 'Bosch' RTT-100 opacimeter, is used to measure the smoke level in the exhaust gas the readings of which are provided as equivalent smoke density in $\left(\mathrm{mg}\right.$ of soot/ $\mathrm{m}^{3}$ of exhaust gases). The concentration of nitrogen oxides in ppm (parts per million, by vol.) present in the exhaust gases was measured by using 'Signal' Series-4000 chemiluminescent analyzer (CLA) that was fitted with a thermostatically controlled heated line. The total unburned hydrocarbons concentration (in ppm) present in the exhaust gases was measured with a 'Ratfisch-Instruments' Series RS55 flameionization detector (FID) that was also fitted with a thermostatically controlled heated line.

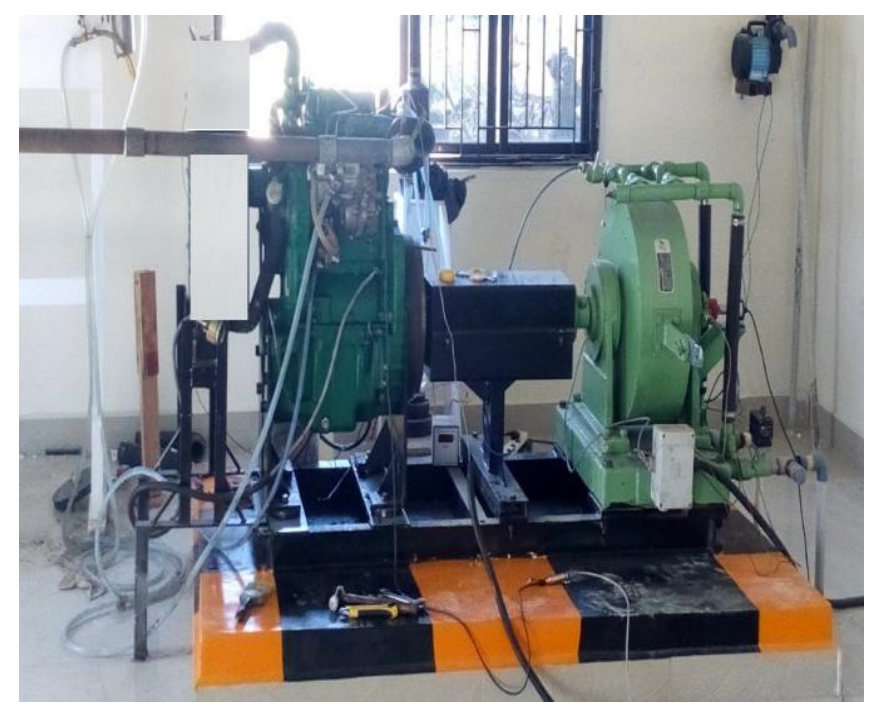

Figure 1: Experimental Setup

Table 1: Engine Specifications and Injection System Basic Data

\begin{tabular}{|c|c|}
\hline \multicolumn{2}{|c|}{$\begin{array}{l}\text { Engine model and type : Kirlosker single-cylinder, four, } \\
\text { stroke, compression ignition, } \\
\text { direct injection, water-cooled. }\end{array}$} \\
\hline Speed & $1500 \mathrm{rpm}$ \\
\hline Engine total displacement & $661 \mathrm{~cm} 3$ \\
\hline Bore/stroke & $87.5 \mathrm{~mm} / 110 \mathrm{~mm}$ \\
\hline Compression ratio & $17.5: 1$ \\
\hline Maximum power & 5.2 HP @ 1500 rpm \\
\hline Maximum torque & 29.0376 Nm @1500rpm \\
\hline opening pressure & 250 bar \\
\hline
\end{tabular}

\section{Properties of Fuels Tested}

Two typical types of straight Bio-diesel oils, viz. safflower and hazelnut oil are tested as supplements of the normal diesel fuel, at blend ratios of $05 / 95 \%, 10 / 90 \%, 15 / 85 \%$ and $20 / 80 \% 25 / 75 \%$ (by vol.) with the conventional diesel fuel.

Diesel fuels which contains very less amount of sulphur content approximately $(0.035 \mathrm{wt} \%)$ forms the base line for present study. To reduce the viscosity of bio-fuels they are to be de-gummed and refined, nearly the edible type without any pre-heating and adding any additives. All important properties of two bio-fuels and diesel are provided in table- 2 . All the values mentioned in the table are the mean values taken from various sites and references mentioned with this paper. In this study it required to note that the cetane number and kinematic viscosity values mentioned are not used computationally. In order to explain qualitatively the relative performance and emissions behavior of different fuel blends they are only referred to for indicative purposes.

Table 2: Fuel Properties

\begin{tabular}{|c|c|c|c|c|}
\hline Fuel & $\begin{array}{c}\text { Density at } \\
15^{0} \mathrm{c} . \\
\mathrm{Kg} / \mathrm{mm}^{3}\end{array}$ & $\begin{array}{c}\text { Kinematic } \\
\text { viscosity at } 40^{\circ} \mathrm{c} . \\
\text { cST }\end{array}$ & $\begin{array}{c}\text { Calorific } \\
\text { value. } \\
\text { MJ } / \mathrm{kg}\end{array}$ & $\begin{array}{c}\text { Flash } \\
\text { point }\end{array}$ \\
\hline Diesel & 837 & 1.3 & 42.70 & 369 \\
Hazelnut & 875 & 3.59 & 42.12 & 425 \\
Corn & 873 & 3.62 & 41.14 & 427 \\
\hline
\end{tabular}




\section{International Journal of Science and Research (IJSR) \\ ISSN (Online): 2319-7064}

Index Copernicus Value (2013): 6.14 | Impact Factor (2015): 6.391

Table 3: Accuracy of Measurements and Uncertainty of Computed Results

\begin{tabular}{|c|c|}
\hline Measurements & Accuracy \\
\hline NOx & $\pm 5 \mathrm{ppm}$ \\
HC & $\pm 0.5 \mathrm{ppm}$ \\
CO & $\pm 0.2 \%$ \\
Smoke opacity & $\pm 0.1 \%$ \\
Speed & $\pm 5 \mathrm{rpm}$ \\
Specific fuel consumption & \pm 1.5 \\
Time & $\pm 5 \%$ \\
Torque & $\pm 0.5 \mathrm{Nm}$ \\
Fuel volumetric rat & \pm 1 \\
Power & \pm 1 \\
\hline
\end{tabular}

\section{Experimental Section, Transesterification Process}

To reduce viscosity of vegetable oils, transesterification method is adopted for preparation of biodiesell. In this process, non-edible oil $(1000 \mathrm{ml})$ was taken in a three way flask. In a beaker, sodium hydroxide $(\mathrm{NaOH}, 12 \mathrm{~g})$ and methanol $\left(\mathrm{CH}_{3} \mathrm{OH}, 200 \mathrm{ml}\right)$ were thoroughly mixed until it is properly dissolved. The solution obtained was mixed with nonedible oil in three way flask and stirred properly. Methoxide solution with non-edible oil was heated to $60^{\circ} \mathrm{C}$ and continuously stirred at constant rate for $1 \mathrm{~h}$. The solution is poured down in a separate beaker and is allowed to settle for $4 \mathrm{~h}$. Glycerin settles at the bottom and methyl ester floats at the top (coarse biodiesel). Methyl ester is separated, heated above $100^{\circ} \mathrm{C}$ and maintained for $10-15 \mathrm{~min}$ to remove untreated methanol. Certain impurities like $\mathrm{NaOH}$ etc. are still dissolved in the obtained coarse biodiesel. These impurities are cleaned up by washing with $350 \mathrm{ml}$ of water for $1000 \mathrm{ml}$ of coarse biodiesel. Cleaned biodiesel is methyl ester of non-edible oil ${ }^{\mathfrak{L}}$.

\section{Parameters Tested and Experimental Procedure}

Engine testing was done in a laboratory at a constant temperature. Engine was started and warmed-up at low idle, long enough to establish the recommended oil pressure, and was checked for any fuel, oil leaks. After completing warm-up procedure, engine was run on no- load condition and speed was adjusted to $1800 \mathrm{rpm}$ by adjusting fuel injection pump. Engine was run to gain uniform speed, after which it was gradually loaded. Experiments were conducted at different levels of load. For each load condition, engine was run at a minimum of $10 \mathrm{~min}$ and data were collected during the last 4-min of operation. Simultaneously, engine exhaust emissions were also determined.

The series of tests are conducted using each of the above mentioned blends, with the engine working at speed of 1500 and at different torque mentioned above. Because of the differences in oxygen content and calorific values of different fuels tested, the analysis is effected at the same engine brake power and not the air fuel ratio or same injected fuel mass.

In each test exhaust smokiness, volumetric fuel consumption rate, and exhaust gas emissions such as carbon monoxide, nitrogen oxides, and total unburned hydrocarbons are measured. From the first measurement brake thermal efficiency (BTHE.) and brake specific fuel consumption (b.s.f.c.) are computed using the fuel sample density and lower calorific value. Table 3 shows the uncertainty of the computed results of various parameters and the accuracy of the measurements.

The analysis of experimental work was started with a preliminary investigation of the compression ignition engine fueled with neat diesel fuel, to find out the exhaust emission levels and engine operating characteristics which constitute a base line can be used to compare with the corresponding cases when using each of the blends forming with the combination of neat diesel and bio-fuel with appropriate proportions. By keeping the same operating conditions the same procedure was repeated for each fuel blend. For every time when the fuel is changed, the lines through which fuel flows were cleaned and then the engine is allowed to run for about 30 minutes to reach and stabilize its new desired conditions.

\section{Results and Discussion}

Test engine was run with different fuels and time for $10 \mathrm{cc}$ fuel consumption was calculated. Among two biodiesels, Hazelnut biodiesel showed lesser viscosity than other oils at various temperatures (Fig. 2), may be due lower density of hazelnut biodiesel than others.

\section{A. Brake Thermal Efficiency (BTHE)}

Fig. 2 shows, the brake thermal efficiency (BTHE.) for the neat diesel fuel, and $20 \%$ blends of the hazelnut and safflower oils with bio-diesels with normal diesel fuel, at various loads. BTHE of diesel fuel is $\mathrm{higher}$ compared with other bio-diesels blends at various loads (Fig. 3). In the listed bio-diesels blends of present work, hazelnutiodiesel blend is showing higher BTHE than remaining blends. BTHE graph of $20 \%$ blend of bio-diesel is as HB20 > SB20. It is also observed that as the load increases BTHE also increases with load up to three fourth of full load from there it starts decreasing.

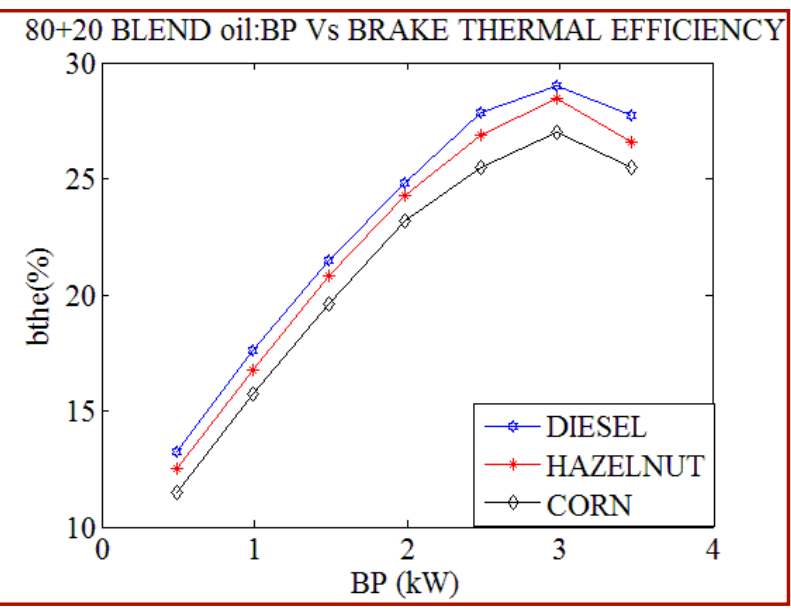

Figure 2: Brake Thermal Efficiency

\section{B. Hydrocarbon (Hc) Emissions}

HC emission of neat diesel fuel is higher when compared with bio-diesels blends of hazelnut and safflower at 


\section{International Journal of Science and Research (IJSR) \\ ISSN (Online): 2319-7064}

Index Copernicus Value (2013): 6.14 | Impact Factor (2015): 6.391

all loads (Fig. 3). Among all bio-diesel blends, Hazelnut is showing lesser $\mathrm{HC}$ emission than other bio-diesel blends. $\mathrm{HC}$ emissions trend at $20 \%$ blend of biodiesel is as $\mathrm{H} 20>$ S20, may be because all biodiesels contain oxygen, which favors better combustion when compared with diesel. Hence, HC emissions are very less for biodiesel. For other blends, trend is similar to that for $20 \%$ blend. As load increases, $\mathrm{HC}$ emissions decrease. However, hazelnut blend HC emissions are less when compared with $20 \%$ blend of other bio-diesel blends.

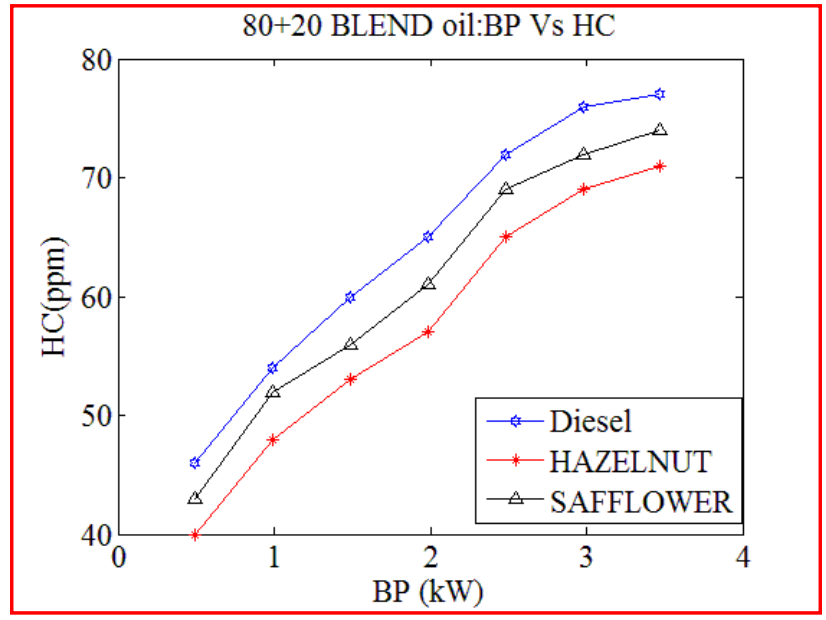

Figure 3: Hydrocarbon Emissions

\section{NOX Emissions}

Fig. 4 shows, the emissions oxides of nitrogen (NOx) in ppm for conventional diesel fuel, and $20 \%$ blends of hazelnut and safflower bio-diesel blended with diesel, and used as fuel in the IC engine at various loads. One can observe that the NOx emitted by all bio-diesel blends are higher than corresponding diesel fuel. According to the discussion of the previous subsection the lower cetane number of vegetable oils (higher ignition delay) may play a role in this increase, apart from the delicate distribution of the fuel-air 'packets' inside the sprays as influenced by the fuel bound oxygen. Among all biodiesels Hazelnut bio-diesel blend is showing minimum NOx emissions than other bio-diesels. $\mathrm{NO}_{\mathrm{x}}$ emissions trend at 20\% blend of biodiesel is as $\mathrm{H} 20>$ S20, may be due to the low cetane number of biodiesel, which lead to ignition lag and causes to accumulate large amount of un burned mixture of air and bio-fuel. This accumulated charge after reaching the self ignition condition will burn at a time causes better combustion than diesel. As a result, the adiabatic flame temperature or maximum temperature inside cylinder is more in case of biodiesels than diesel. Hence, this catalyzes reactions for oxidation of nitrogen and hence NOX emissions are more for biodiesels. For other blends, trend is similar to that for $20 \%$ blend. As load increases, NOX emission increases. However, emissions are less when compared with $20 \%$ blend.

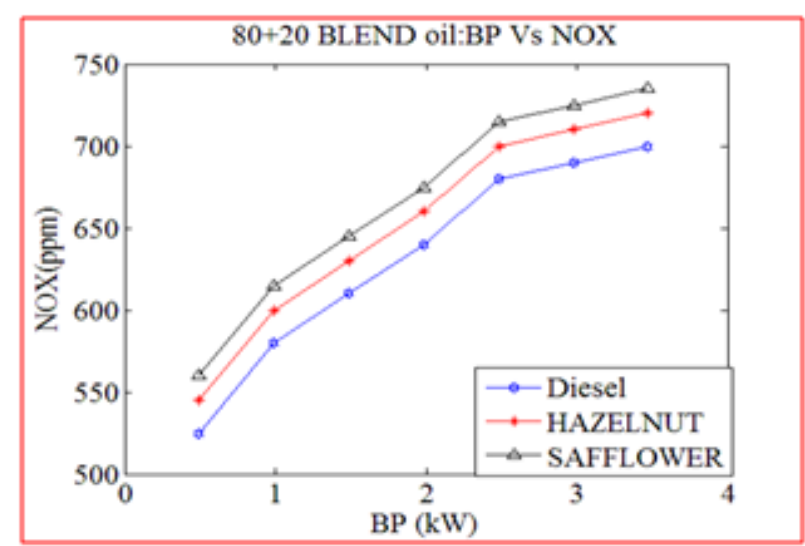

Figure 4: $\mathrm{NO}_{\mathrm{X}}$

\section{Co Emissions}

Fig. $5 \mathrm{HC}$ emission of neat diesel fuel is higher when compared with bio-diesels blends of hazelnut and safflower at all loads (Fig. 3). Among all bio-diesel blends, Hazelnut is showing lesser $\mathrm{CO}$ emission than other bio-diesel blends. $\mathrm{CO}$ emissions trend at $20 \%$ blend of biodiesel is as $\mathrm{H} 20>$ S20, may be because all biodiesels contain oxygen, which favors better combustion when compared with diesel. Hence, CO emissions are very less for biodiesel. For other blends, trend is similar to that for $20 \%$ blend. As load increases, HC emissions decrease. However, hazelnut blend CO emissions are less when compared with $20 \%$ blend of other bio-diesel blends.

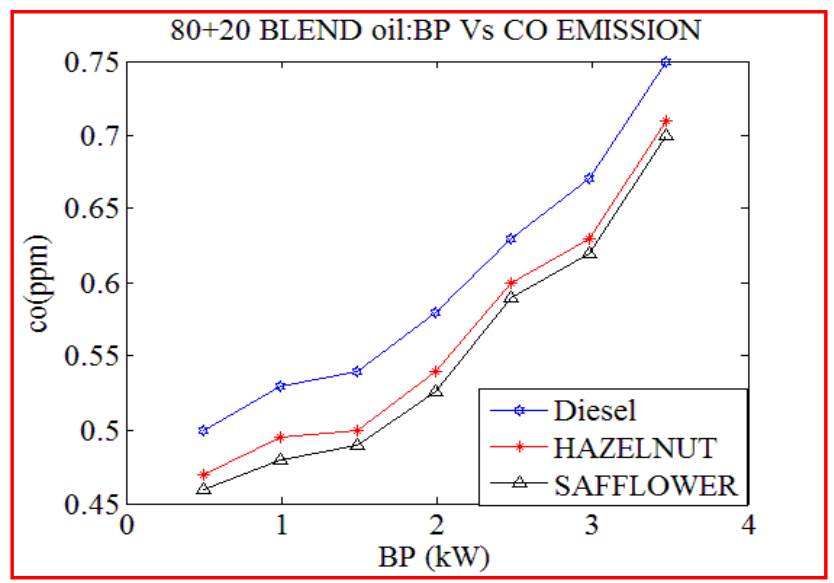

Figure 5: Co Emissions

\section{E. Smoke Density}

Fig.6 shows the smoke density for the conventional diesel fuel, and $20 \%$ blends of the hazelnut and crambe bio-diesel blended with diesel fuel, at different loads. One can observe that the density of all bio-fuel blends is higher than the ones for the corresponding neat diesel fuel. 
International Journal of Science and Research (IJSR)

ISSN (Online): 2319-7064

Index Copernicus Value (2013): 6.14 | Impact Factor (2015): 6.391

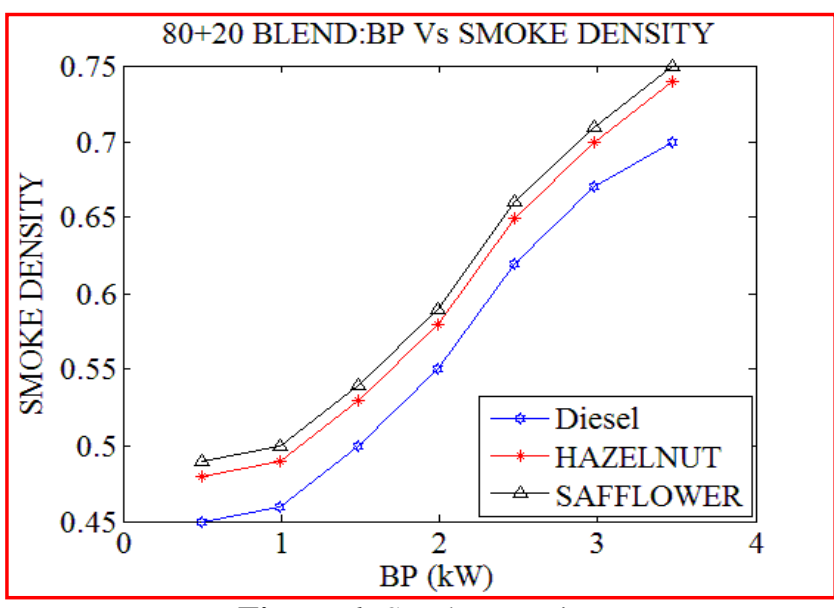

Figure 6: Smoke Density

\section{F. Brake Specific Fuel Consumption}

Fig. 7 shows the brake specific fuel consumption (b.s.f.c.) expressed in $\mathrm{kg} / \mathrm{kW} \mathrm{h}$ (kilograms per kilowatt and hour) for the conventional diesel fuel, and blends of $20 \%$ of hazelnut and safflower bio-diesel blends and neat diesel fuel at different loads. The mass flow rate of fuel blend is calculated from the respective volume flow rate value which is measured and the density of the fuel blends which is computed by considering the densities of the fuel using and the ratio of fuel blends involved in the experimental work. Since the evaluation of work is made on the constant speed and same load which is translated in to the same engine power, and these values are proportional to the mass flow rate of fuel. It is to be observed that the air mass flow rate remains same under the same operating conditions.

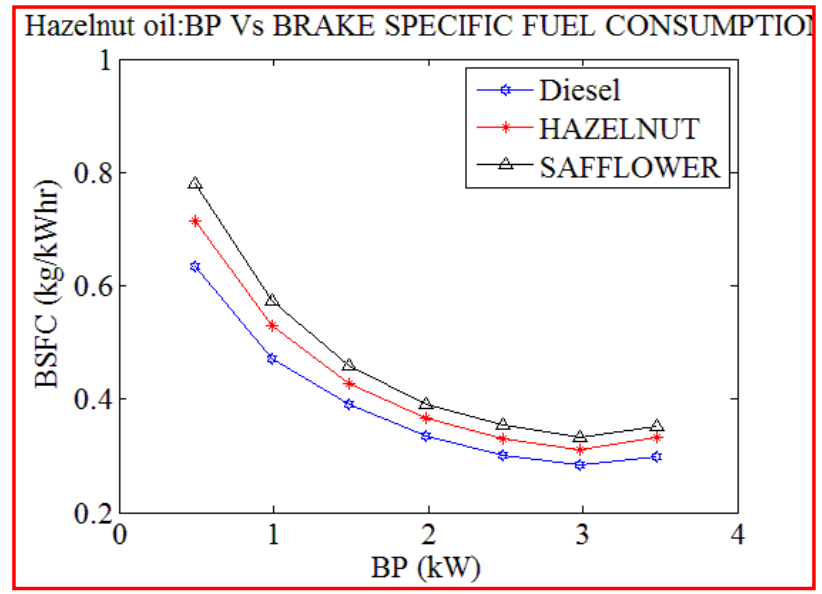

Figure 6: BSFC

\section{G. Exhaust Gas Temperatures}

Exhaust gas temperature Exhaust gas temperature (EGT) varied with load and the results for different fuels are presented in Figure 8. EGT of all the tested fuels increased with load. EGT of B20 was higher than that of diesel fuel at the highest load due to the blends' higher viscosities, which resulted in poorer atomization, poorer evaporation, and extended combustion during the exhaust stroke. As the amount of bio-fuel content increases then viscosity also increases, and, as a result, EGT of the blends was higher than that of diesel fuel due to deterioration in combustion and more fuel being oxidized.

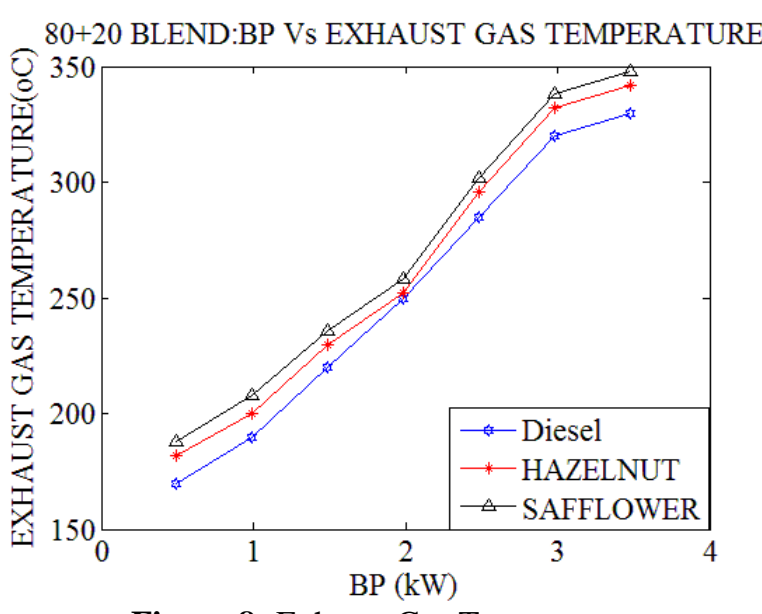

Figure 8: Exhaust Gas Temperatures

\section{Summary and Conclusions}

An experimental work was carried out to evaluate and compare the performance parameters and exhaust emission levels of two different bio-fuels viz. hazelnut oil and safflower oil as supplements in the diesel fuel at blend ratios of 20/80 (by vol.).

A series of experiments have performed with the above biodiesel blends, with the engine working at various lods. In each test exhaust smokiness, exhaust gas, temperatures and exhaust regulated gas emissions such as nitrogen oxides (NOx), carbon monoxide (CO), and total unburned hydrocarbons (HC) are analyzed. brake specific fuel consumption and Brake thermal efficiency were computed from measured fuel volumetric flow rate and calorific values.

The exhaust smoke emissions were reduced by the use of all bio-diesel blends along with the respective neat conventional diesel fuels, hazelnut oil blends perform better when compared with remaining blends.

The NOx emissions were marginally increased with the use of bio-diesel blends as fuel when compare to those of the neat conventional diesel fuel, with this increase being higher the higher the percentage of bio-fuel in the blend.

The $\mathrm{CO}$ emissions were considerably decreased with the use of all bio-fuel blends with respect to those of the neat diesel fuel, with this increase being higher the higher the percentage of bio-fuel in the blend.

The HC emissions were decreased with the use of all biodiesel blends with respect to those of the neat diesel fuel, with this being further decreases as the higher the percentage of bio-fuel in the blend.

The engine brake thermal efficiency is higher for neat diesel fuel than hazelnut and safflower bio-diesel blends and for blends of hazelnut oil which is having less BTHE than diesel fuel and giving better performance than remaining bio-diesel blends. 


\section{International Journal of Science and Research (IJSR) \\ ISSN (Online): 2319-7064}

Index Copernicus Value (2013): 6.14 | Impact Factor (2015): 6.391

\section{References}

[1] Rakopoulos CD, Giakoumis EG. Diesel engine transient operation - principles of operation and simulation analysis. London: Springer; 2009.

[2] Pulkrabek WW. Engineering fundamentals of internal combustion engines. 2nd ed. New Jersey: Pearson Prentice-Hall; 2004.

[3] Levendis YA, Pavlotos I, Abrams RF. Control of diesel soot, hydrocarbon and NOx emissions with a particulate trap and EGR. SAE paper no. 940460; 1994.

[4] Larsen C, Oey F, Levendis YA. An optimization study on the control of NOx and particulate emissions from diesel engines. SAE paper no. 960473; 1996.

[5] Komninos NP, Rakopoulos CD. Numerical investigation into the formation of $\mathrm{CO}$ and oxygenated and noNOxygenated hydrocarbon emissions from isooctaneand ethanol-fueled HCCI engines. Energy Fuels 2010; 24:1655-67.

[6] Miyamoto N, Ogawa H, Nabi MN. Approaches to extremely low emissions and efficient diesel combustion with oxygenated fuels. Int J Engine Res 2000;1:71-85.

[7] Pepiot-Desjardins P, Pitsch H, Malhotra R, Kirby SR, Boehman AL. Structural group analysis for soot reduction tendency of oxygenated fuels. Combust Flame 2008;154:191-205.

[8] Rakopoulos CD, Michos CN, Giakoumis EG. Studying the effects of hydrogen addition on the second-law balance of a biogas-fuelled spark ignition engine by use of a quasi-dimensional multi-zone combustion model. Proc Inst Mech Eng, Part D, J Autom Eng 2008;222:2249-68.

[9] Abu-Jrai A, Rodriguez-Fernandez J, Tsolakis A, Megaritis A, Theinnoi K, Cracknell RF, et al. Performance, combustion and emissions of a diesel engine operated with reformed EGR. Comparison of diesel and GTL fuelling. Fuel 2009;88:1031-41.

[10] Barlow RS, Karpetis AN, Frank JH, Chen J-Y. Scalar profiles and NO formation in laminar opposed-flow partially premixed methane/air flames. Combust Flame 2001;127:2102-18.

[11] Hansen AC, Kyritsis DC, Lee CF. Characteristics of biofuels and renewable fuel standards. In: Vertes AA, Blaschek HP, Yukawa H, Qureshi N, editors. Biomass to biofuels - strategies for global industries. New York: John Wiley; 2009.

[12] Rickeard DJ, Thompson ND. A review of the potential for bio-fuels as transportation fuels. SAE paper no. 932778; 1993.

[13] Hansen AC, Zhang Q, Lyne PWL. Ethanol-diesel fuel blends - a review. Bioresour Technol 2005;96:277-85.

[14] Rakopoulos CD, Antonopoulos KA, Rakopoulos DC, Hountalas DT, Giakoumis EG. Comparative performance and emissions study of a direct injection diesel engine using blends of diesel fuel with vegetable oils or bio-diesels of various origins. Energy Convers Manage 2006;47:3272-87.

[15] Rakopoulos CD, Rakopoulos DC, Giakoumis EG, Dimaratos AM. Investigation of the combustion of neat cottonseed oil or its neat bio-diesel in a HSDI diesel engine by experimental heat release and statistical analyses. Fuel 2010;89:3814-26.
[16] Rakopoulos CD, Antonopoulos KA, Rakopoulos DC. Experimental heat release analysis and emissions of a HSDI diesel engine fueled with ethanol-diesel fuel blends. Energy 2007;32:1791-808.

[17] Rakopoulos DC, Rakopoulos CD, Kakaras EC, Giakoumis EG. Effects of ethanol-diesel fuel blends on the performance and exhaust emissions of heavy duty DI diesel engine. Energy Convers Manage 2008;49:315562.

[18] Rakopoulos DC, Rakopoulos CD, Hountalas DT, Kakaras EC, Giakoumis EG, Papagiannakis RG. Investigation of the performance and emissions of a bus engine operating on butanol/diesel fuel blends. Fuel 2010;89:2781-90.

[19] Agathou MS, Kyritsis DC. An experimental comparison of non-premixed biobutanol flames with the corresponding flames of ethanol and methane. Fuel 2011;90:255-62.

[20] Barlow RS, Ozarovsky HC, Karpetis AN, Lindstedt RP. Piloted jet flames of $\mathrm{CH} 4 / \mathrm{H} 2 /$ air: experiments on localized extinction in the near field at high Reynolds numbers. Combust Flame 2009;156:2117-28.

[21] Rakopoulos CD, Kosmadakis GM, Pariotis EG. Evaluation of a combustion model for the simulation of hydrogen spark-ignition engine using a CFD model. Int J Hydrogen Energy 2010;35:12545-60.

[22] Graboski MS, McCormick RL. Combustion of fat and vegetable oil derived fuels in diesel engines. Prog Energy Combust Sci 1998;24:125-64.

[23] Demirbas A. Biodiesel fuels from vegetable oils via catalytic and non-catalytic supercritical alcohol transesterifications and other methods: a survey. Energy Convers Manage 2003;44:2093-109.

[24] Srivastava A, Prasad R. Triglycerides-based fuels. Renew Sustain Energy Rev 2000;4:111-33.

[25] Papayannakos N, Rakopoulos CD, Kyritsis S, Lappas A, Chatzigakis A, Chlivinos G, et al. Pilot production and testing of bio-diesel produced from Greek feedstocks. In: Frangopoulos C, Rakopoulos C, Tsatsaronis G, editors. Proc of the 19th Int Conf 'ECOS 2006', vol. 3, Crete, Greece, July 12-14, 2006, p. 1489-97.

[26] Canakci M, Erdil A, Arcaklioglu E. Performance and exhaust emissions of a biodiesel engine. Appl Energy 2006;83:594-605.

[27] Rakopoulos CD, Antonopoulos KA, Rakopoulos DC, Kakaras EC, Pariotis EG. Characteristics of the performance and emissions of a HSDI diesel engine running with cottonseed oil or its methyl ester and their blends with diesel fuel. Int J Vehicle Des 2007;45:200_ 21.

[28] Rakopoulos CD, Rakopoulos DC, Hountalas DT, Giakoumis EG, Andritsakis EC. Performance and emissions of bus engine using blends of diesel fuel with biodiesel of sunflower or cottonseed oils derived from Greek feedstock. Fuel 2008;87:147-58.

[29] Benjumea P, Agudelo J, Agudelo A. Effect of altitude and palm oil biodiesel fuelling on the performance and combustion characteristics of a HSDI diesel engine. Fuel 2009;88:725-31.

[30] Bueno AV, Velasquez JA, Milanez LF. Heat release and engine performance effects of soybean oil ethyl ester blending into diesel fuel. Energy 2010. doi:10.1016/j.energy.2010.07.030. 
[31] Barsic NJ, Humke AL. Performance and emissions characteristics of a naturally aspirated diesel engine with vegetable oil fuels. SAE paper no. 810262; 1981.

[32] Fort EF, Blumberg PN, Staph HE, Staudt JJ. Evaluation of cottonseed oils as diesel fuel. SAE paper no. 820317; 1982.

[33] Jacobus MJ, Geyer SM, Lestz SS. Taylor WD, Risby TH. Single-cylinder diesel engine study of four vegetable oils. SAE paper no. 831743; 1983.

[34]Zubik J, Sorenson SC, Goering CE. Diesel engine combustion of sunflower oil fuels. Trans ASAE 1984;27:1252-6.

[35] Rakoqoulos CD. Comparative performance and emission studies when using olive oil as a fuel supplement in DI and DI Diesel engines. Renew Energy 1992;2:327-31.

[36] Shaheed A, Swain E. Combustion analysis of coconut oil and its methyl esters in a diesel engine. Proc Inst Mech Eng, Part A 1999;213:417-25.

[37] Agarwal D, Agarwal AK. Performance and emissions characteristics of Jatropha oil (preheated and blends) in a direct injection compression ignition engine. Appl Therm Eng 2007;27:2314-23.

[38] Bajpai S, Sahoo PK, Das LM. Feasibility of blending Karanja vegetable oil in petro-diesel and utilization in a direct injection diesel engine. Fuel 2009;88:705-11.

[39] Haldar SK, Ghosh BB, Nag A. Studies of comparison of performance and emission characteristics of a diesel engine using three degummed non-edible vegetable oils. Biomass Bioenergy 2009;33:1013-8.

[40] Rakopoulos CD, Giakoumis EG. Second-law analyses applied to internal combustion engines operation. Prog Energy Combust Sci 2006;32:2-47.

[41] Rakopoulos CD, Antonopoulos KA, Rakopoulos DC, Hountalas DT. Multi-zone modeling of combustion and emissions formation in DI diesel engine operating on ethanol-diesel fuel blends. Energy Convers Manage 2008;49:625-43.

[42] Rakopoulos CD, Antonopoulos KA, Rakopoulos DC. Development and application of a multi-zone model for combustion and pollutants formation in a direct injection diesel engine running with vegetable oil or its bio-diesel. Energy Convers Manage 2007;48:1881-901.

[43] Rakopoulos CD, Antonopoulos KA, Rakopoulos DC. Multi-zone modeling of diesel engine fuel spray development with vegetable oil, bio-diesel or diesel fuels. Energy Convers Manage 2006;47:1550-73.

[44] Abolle A, Kouakou L, Planche H. The viscosity of diesel oil and mixtures with straight vegetable oils: palm, cabbage palm, cotton, groundnut, copra and sunflower. Biomass Bioenergy 2009;33:1116-21.

[45] Varde KS. Bulk modulus of vegetable oil-diesel fuel blends. Fuel 1984;63:713-5.

[46] Heywood JB. Internal combustion engine fundamentals. New York: McGraw- Hill; 1988.

[47] Glassman I. Combustion. 2nd ed. Orlando: Academic Press; 1987.

[48] Stradling R, Gadd P, Singer M, Operti C. The influence of fuel properties and injection timing on the exhaust emissions and fuel consumption of an Iveco heavy duty diesel engine. SAE paper no. 971636; 1997.

[49] Ferguson CR. Internal combustion engines. New York: Wiley; 1986

Volume 5 Issue 6, June 2016 www.ijsr.net 